\title{
ROLE OF ANTI-BRAND WEBSITES ON BRAND IMAGE
}

\author{
Mana Farshid, Lulea University of Technology, Sweden \\ Leila Ashrafi, Lulea University of Technology, Sweden \\ Åsa Wallström, Lulea University of Technology, Sweden \\ Anne Engström, Lulea University of Technology, Sweden
}

\begin{abstract}
Since customers are facilitated through the internet and many-to-many communication, they can easily and conveniently share their opinions with others. Anti-brand websites operate as forums for high-level empowered electronic word-of-mouth exchanges. This study has investigated the role of anti-brand websites on brand image. The scripted data of focus group discussions have been analyzed using Leximancer, a textual analysis tool, because it can recognize themes and concepts that show customers' perspectives and determine the core concepts that are most highlighted or criticized by complainers and activists.
\end{abstract}

\section{INTODUCTION}

The internet has altered the balance of power between customers and companies, as well as the methods of corporate branding, and precipitated radical marketing-driven changes to the structures and cultures of successful businesses (Pitta \& Fowler, 2005; Travis, 2001). Customers are using the internet as a tool to achieve a louder voice. Pitt et al. (2002) has argued that the easy access of consumers to accurate, updated, and unbiased information on the internet gives them the ability to communicate with other consumers and other firms in the public domain. They can demonstrate their dissatisfaction or anger and reach larger numbers of people to express themselves (Pitt et al., 2002).

The volume of customers' ideas and the information they provide about their experiences with a brand are increasing, which makes it possible for other customers to base decisions on this information (Karakaya \& Barnes, 2010). Consumers can spread their message and share it with other consumers, at both individual and community levels, and they have begun to use antibrand websites as weapons of empowerment (Kuchuk, 2008) People with shared ideas and bad experiences or feelings regarding a brand can gather on an anti-brand website and talk about what has happened to them; dissatisfied customers can complain and discuss their bad experience with a brand. If customers complain and show their dissatisfaction with products, the resulting negative word-of-mouth can affects companies' reputation or sales if the issue in question remains unsolved (Breitsohl et al., 2010).

Brands and companies can be negatively affected by such complaints in different ways, from losing their positive image or reputation among customers to decreased sales and loss of market share. Brands can be targeted by anti-brand websites that threaten their image and reputation. This obviously can be a serious issue for managers who may not be well prepared to respond (Kay, 2006). The aim of this research is to investigate the role of anti-brand websites on brand image from customers' points of view, determine how the role of anti-brand websites can be characterized, and examine how brand image can be deeply disposed by these websites.

\section{ANTI-BRAND WEBSITE}

The internet has accelerated and developed the means of communication among people; one of the primary vehicles that the internet provides is forums. According to Bailey (2004), these forums provide opportunities for customers to express their anger and complaints through the website and facilitate customer-to-customer communication. For example, activists can build stronger movements if they use the internet as a tool to broadcast their message and communicate/interact with large numbers of people with the same idea. Anti-brand sites constitute a higher level source of empowerment for consumers (Kucuk \& Krishnamurthy, 2007).

Online activities in terms of protest and boycott take different forms, such as cyber-attacks or large email campaigns, and antibrand sites are one of the most improved and biggest sources of online protests that consumers have built using higher level sources of empowerment (Vegh, 2003; Kucuk, 2008; Kucuk \& Krishnamurthy, 2007). The fundamental goal of anti-brand sites is to criticize the market and social position of a particular targeted brand and to introduce a negative online identity and brand value through negative language and easy-to-remember domains (Kucuk \& Krishnamurthy, 2007; Krishnamurthy \& Kucuk, 2009; Kay, 2006; Baily, 2004). 
Complaint forums provide a platform through which customers can express their experiences and comments, either privately or publicly, to share information with other customers. Customers also use these forums to find a solution for what has happened to them. Anti-brand websites are intended to create a negative identity for a brand; customers not only share their purchasing failures, but also their concerns about extended issues, such as environmental, cultural, legal, and political issues (Krishnamurthy \& Kucuk, 2009).

The speech and communication forms used on anti-brand websites can be categorized into market, ideological, and transactional speech. Market speech attacks the brand by using a specialist in marketing, and ideological attacks criticize personal or national issues. Transactional speech targets those who did not succeed in transactions. Among these three forms of speech, market speech has the biggest effect on brand value (Krishnamurthy \& Kucuk, 2009).

From the perspective of those who are engaging with these websites and their main purpose, Kucuk (2008) categorized the anti-brand sites into four types: experts, symbolic haters, complainers, and opportunists. Expert anti-brand sites' main focus is on market information and analyses. They generally take stands against consumerism and the companies that market around this culture. For example, 'McCruelty' discusses McDonalds' damaging operations in rainforests and issues related to the ethical treatment of animals, and Walmart-blows.com discusses employment discrimination (Kay, 2006; Kucuk, 2008).

Brands with high brand awareness are targeted by symbolic haters who use negative word-of-mouth to sully a brand's achievements. For example, people who hate Starbucks offer comments that are not as reliable as those of experts because the haters' comments are based mainly on personal tastes (Kucuk, 2008). These complainers express anger and opposition mainly relevant to the brand's products and services. Opportunists use media activities and information to find fake news or rumors about a brand to call attention to specific websites (Kucuk, 2008).

Many researchers have investigated customer complaints and customer activities such as boycotts and protests (Sen et al., 2001). In addition, negative word-of-mouth (WOM) and its effects on consumers' opinions and their behavior have been the topic of several studies (Bickart \& Schindler, 2001). O’Reilly and Marx (2011) showed that in the online world strangers' reviews and comments are much more acceptable among people who would pay less attention to them in real-world circumstances.

\section{BRAND IMAGE}

Kucuk (2008) suggested that anti-brand websites, as a type of online WOM, have significant influence on brand identity and image; they can affect customer buying behavior and buying decisions directly or indirectly and they can change the market share of a brand. Consequently, these websites play a noticeable and undeniable role with regard to different aspects of a brand. Brand image is one of these aspects; it describes customers' perceptions, thoughts, and feelings about a brand, which reflects brand associations and creates uniqueness in customers’ memory (Keller, 1993, Webster \& Keller, 2004).

Brand image is an influential factor in profits and long-term cash flow of a company. It affects how ready customers will be to pay first prices, their buying decisions, and the company's ability to maintain competitiveness (Yoo \& Donthu, 2001). Therefore, analyzing and investigating the effect of anti-brand websites and brand image are interesting areas of research that result in managerial suggestions for the brands.

\section{RESEARCH METHODOLOGY}

To investigate the role of anti-brand websites on brand image, researchers should gather as much detail as possible to develop a clear understanding of the problem; in this case, a qualitative research approach has been chosen (Saunders \& Lewis, 2007). To determine respondents' interests, focus group interviews are preferred as the research strategy. The advantage of this strategy is the opportunity to interact with respondents, which yields a better understanding of their answers and deeper insight into the concepts via respondent gestures and body language. Two focus groups with a total of 14 participants were conducted in Sweden. The first group included 6 active soft drink consumers and the other contained 8 electronic device users (e.g., personal computer, smart phone, music player).

For the purpose of this research, the two strong brands of Coca-Cola and Apple were chosen based on the pilot study because strong brands can increase the possibility of becoming a target of attack. If strong brands face difficulties, they can become a subject of criticism, customer attacks, or anti-brand campaigns (Kay, 2006; Kuchuk, 2008). 
Moreover, anti-brand websites like killercoke.org and ihateapple.net have the characteristics of using visual expression, memorable domain names, and critical language to create a negative online identity for the targeted brand (Krishnamurthy \& Kucuk, 2009).

Participants were invited to take part in groups and asked to express their general views and ideas about the brand. This allows for in-depth discussion of brand image, products, and activities (Steward et al., 2007). After an illustration of anti-brand websites, the discussion continued based on participants' perceptions and views about these websites. Finally, participants were free to describe their impressions from the anti-brand sites and whether they believe these sites can affect customers' perceptions of brands. To determine the role of the anti-brand website on brand image, we used computer-aided content analysis to study attributes of scripted focus group discussions. As Kassarjian (1977) mentioned, not surprisingly the exchange of communication and values in the marketplace takes the form of the written or spoken word or images and symbols. Content analysis is a research technique used to describe and quantify elements of communication in a systematic and objective manner (Kassarjian, 1977).

Leximancer is a data-mining tool modeled on content analysis that provides a platform for the qualitative interpretation of concepts (Smith, 2003; Smith \& Humphreys, 2006). This software uses a new method to transform lexical co-occurrence data that emerge from the text into semantic patterns or relational analysis of themes and concepts (Smith \& Humphreys, 2006; Martin \& Rice, 2007; Rooney, 2005). Based on Smith and Humphreys’ (2006) discussion, Leximancer has stability from its coder reliability and reproducibility given the same system settings (Rooney et al., 2011; Smith \& Humphreys, 2006).

\section{Results}

By entering all the textual data we drew from the discussions with participants in the two focus groups, we aimed to identify specific themes and concepts that emerged from these conversations to explain influential attributes of anti-brand websites on brand image. The resulting concept maps from the Leximancer analysis are provided in Figures 1 and 2 for each focus group. In the first focus group discussing Coca-Cola and the anti-brand website killercoke.org, participants mostly mentioned concepts such as "people" and "company." Regarding this dominant concept, participants said that people around the world buy this product every day so they will suggest this anti-brand website to their friends to make them aware that they might be able to "trust" the "website". The group had varying ambiguous reactions to reading the article on the site that talked negatively about Coca-Cola. They said they might "read" the article if it is grounded scientifically, and they will share the article to make their friends aware of it. Some mentioned that they would actively participate in an online boycott if it were organized well.

Participants believed that Coca-Cola is a multinational company with a monopolistic and imperialistic strategy; specifically, they believed the dominant sponsorship of Coca-Cola is embarrassing, saying “everywhere you look you see Coca-Cola!” They said this brand should use its money to make changes regarding its previous bad reputation and image. The conversation also touched on the amount of sugar people take in from this drink and how bad such sugar consumption can be for health. Indeed, "health" was one of the important issues that participants seemed to mention based on the concept map. Many conversations addressed environmental issues created by Coca-Cola and raised in the website, which made participants think about these issues. They continued conversation around the plastic "bottles" used by this brand and its consumers. The most important concept was "taste"; some participants supposed that the popularity of Coca-Cola, particularly for children, derives from its taste and people consume it “because they don’t have so many choices when they eat outside!”

The second focus group discussion was about Apple and the anti-brand website of ihateapple.net. The term "product” was the prominent concept and participants had discussions around Apple's "different" products. They believed that the "quality" of products is high but also that they are "expensive" and "high priced.” They also mentioned that the "company" and the brand are different from the product, which means Apple's marketing strategy entices people to "buy" its products increasingly. Participants talked about the "computer" and compared Apple with other brands. They said they did not get that much "time" to learn how to work the computer or "iPhone". Some discussions involved whether participants would recommend Apple products to their friends.

Participants mentioned their ambiguity about the content of the "website" and also their belief that it is natural for such a big brand to be criticized: "It is normal to have people against the product!" Furthermore, it was important for the participants to identify the people engaging with the anti-brand website, and they criticized the arguments for not having logical and technical bases. Although people look to solve their problems by reviewing blogs, videos, and news about the brand, participants thought the website looked awkward and useless. 
The resulting maps in Figures 1 and 2 indicate that quite different conversations emerged for each brand and the anti-brand website; however, common themes were present. In the two analysis maps shown in Figures 1 and 2, a common theme and concept emerged regarding the ambiguity of participants toward the anti-brand website. This indicates that it is important for participants to trust the website before they follow or share the content with their friends. Assuming that consumers trust the anti-brand websites, it is crucial for managers to be aware that their brand image can be affected in this regard. Managers can engage, collect, and follow the opinion of people who are not invested in their brand. This can help them find a way to satisfy current customers and attract new ones by revising their product and brand strategy. Based on the discussions and concept maps, some issues were not familiar to some participants, but the anti-brand website made them aware of these issues. They thought about their previous experiences and future purchases and some were even motivated to engage with the negative wordof-mouth. Managers should consider that people are able to share content with their friends, which will inevitably result in some negative brand image.

\section{CONCLUSION}

To understand the role of anti-brand websites and their effect on brand image, this research has analyzed focus group discussions using content analysis. Accordingly, through in-depth analysis of anti-brand websites and people's perceptions and by determining the core concepts that are more frequently highlighted or criticized by complainers and activists, marketers can develop different strategies for saving the brand image. Due to the exploratory nature of this research, this study is not without limitations. Only two anti-brand websites were analyzed in this case, which does not allow for appropriate reliability and validity testing for this study. This may lead to choosing other anti-brand websites for the purpose of analyzing the concepts of other brands.

Because of the qualitative nature of this research, the interpretation of concept maps is largely subjective, which introduces the possibility of finding different interpretations and implications in analyzing the Leximancer maps. Since this study was crosssectional in nature and provided a snapshot in time, it is likely that different maps would have resulted if the focus groups had been conducted at a different time. This gives rise to the opportunity for a longitudinal study to compare results over time. Another further avenue for research would be designing and preparing strategic plans for managers to suggest appropriate actions to counter the activities of anti-brand websites.

\section{FIGURES}

Figure 1: Leximancer map of Coca-Cola

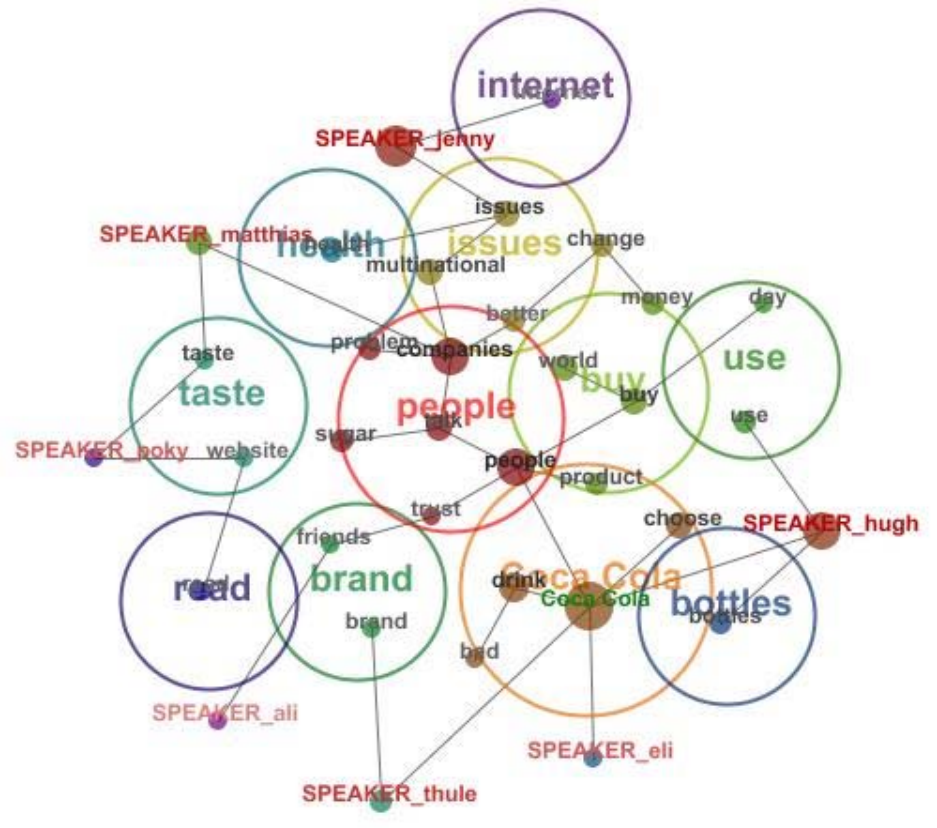

Figure 2: Leximancer map of Apple 


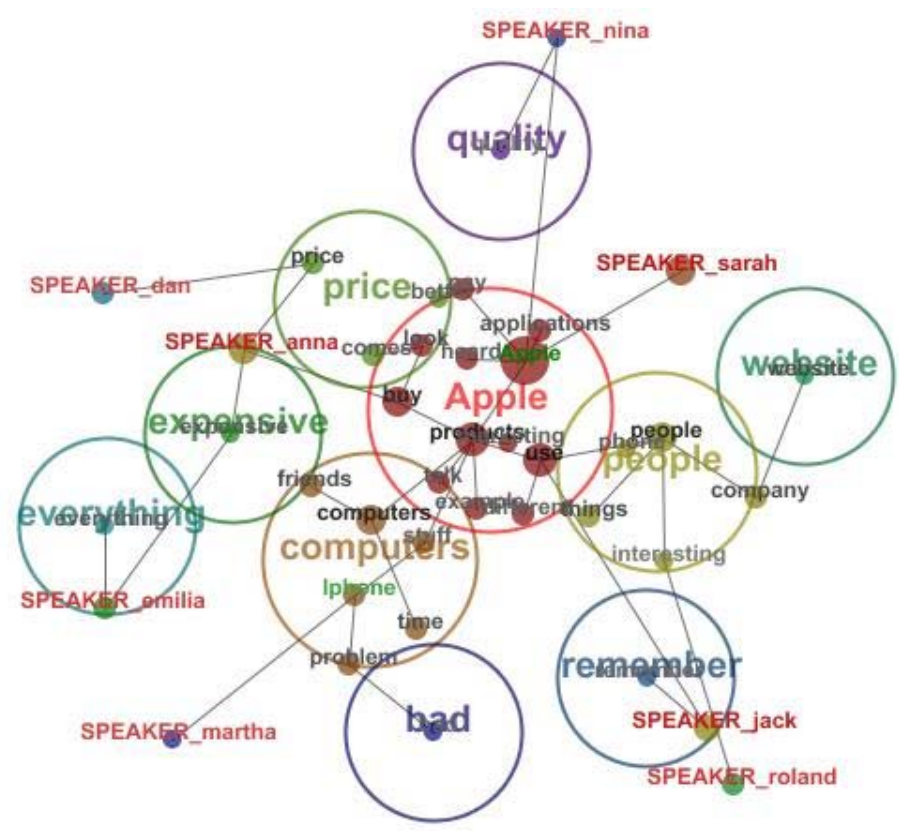

\section{REFERENCES}

Bailey, A. A. (2004). Thiscompnysucks.com: the use of the internet in negative consumer-to-consumer articulations. Journal of Marketing Communications, 10(3), 169-182.

Bickart, B., \& Schindler, R. M. (2001). Internet forums as influential sources of consumer information. Journal of Interactive Marketing, 15(3), 31-40.

Breitsohl, J., Khammash, M., \& Griffiths, G. (2010). E-business complaint management: perceptions and perspectives of online credibility. Journal of Enterprise Information Management, 23(5), 653-660.

Karakaya, F., \& Barnes, N. G. (2010). Impact of online reviews of customer care experience on brand or company selection. Journal of Consumer Marketing, 27(5), 447-457.

Kassarjian, H. H. (1977). Content analysis in consumer research. Journal of Consumer Research, 4(1), 8-18.

Kay, M.J. (2006). Strong brands and corporate brands. European Journal of Marketing. 40(7/8), 742-760.

Keller, K.L. (1993). Conceptualizing, measuring, and managing customer-based brand equity. Journal of Marketing, 53, 1-22.

Krishnamurthy, S., \& Kucuk, S. U. (2009). Anti-branding on the internet. Journal of Business Research, 62, 1119-1126.

Kuchuk, S. U., \& Krishnamurthy, S. (2007). An analysis of consumer power on the internet. Journal of Technovation, 27, 4756.

Kucuk, S. U. (2008). Negative double jeopardy: the role of anti-brand sites on the internet. Journal of Brand Management. 15, 209-222.

Martin, N. J., \& Rice, J. L. (2007). Profiling enterprise risks in large computer companies using the Leximancer software tool. Journal of Risk Management, 9, 188-206. 
O'Reilly, K., \& Marx, Sh. (2011). How young, technical consumers assess online WOM credibility. International Journal of Qualitative Market Research, 14(4), 330-359.

Pitt, L. F., Berthon, P. R., Watson, R. T, \& Zinkhan, G. M. (2002). The internet and the birth of real consumer power. Journal of Business Horizons, 45(4), 7-14.

Pitta, D. A., \& Fowler, D. (2005). Internet community forums: an untapped resource for consumer marketers. Journal of Consumer Marketing, 22(5), 265-274.

Rooney, D. (2005). Knowledge, economy, technology and society: the politics of discourse. Telematics and Informatics, 22(4), 405-422.

Rooney, D., McKenna, B., \& Barker, J. R. (2011). History of ideas in management communication quarterly. Journal of Management Communication Quarterly, 25(4), 583-611.

Saunders, M., Lewis, P., \& Thornhill, A. (2007). Research method for business students. 4th ed. Prentice Hall.

Sen, S., \& Lerman, D. (2007). Why are you telling me this? An examination into negative consumer reviews on the web. Journal of Interactive Marketing, 21(4), 76-94.

Smith, A. E. (2003). Automatic extraction of semantic networks from text using Leximancer. Proceedings of HLT-NAACL, Edmonton, 23-24.

Smith, A. E., \& Humphreys, M. S. (2006). Evaluation of unsupervised semantic mapping of natural language with Leximancer concept mapping. Journal of Behavior Research Methods, 38(2), 262-279.

Steward, D. W., Shamdasani, P. N., \& Rook, D.W. (2007). Focus groups: theory and practice. 2nd ed.

Travis, D. (2001). Branding in the digital age. Journal of Business Strategy, May/June, 14-18.

Vegh, S. (2003). Classifying forms of online activism: the case of cyber protests against the World Bank. Cyberactivism: online activism in theory and practice, Routledge London.

Webster, F.E., \& Keller, K.L. (2004). A roadmap for branding in industrial markets. Journal of Brand Management, 11(5), 388-402.

Yoo, B., \& Donthu, N. (2001). Developing and validating multidimensional consumer-based brand equity scale. Journal of Business Research, 52, 1-14. 